\title{
Student participation in university administration: factors, approaches and impact
}

\author{
Haque Shahabul ${ }^{1} \cdot$ Abdulghani Muthanna $^{2}$ (ID) $\cdot$ Monira Sultana $^{3}$
}

Received: 12 April 2021 / Accepted: 1 December 2021 / Published online: 16 December 2021

(C) The Author(s) 2021

\begin{abstract}
What motivates students to participate in student organizations, how students participate in university administration decision-making, and how such participation influences students' overall development is under-researched in Bangladesh. Therefore, to uncover such dynamics we employed document analyses, observations, and in-depth interviews with 25 university administrators, teachers, students, and social and cultural activists. As a result of this research, the findings reveal several factors behind students' participation in student organizations that also participate in university administration. While such participation is positive for students' overall development, the participation in university administration is not that effective. This requires of the university administration to reconsider students' voices and interests while making decisions related to students' overall development.
\end{abstract}

Keywords Bangladesh · Higher education · Student participation · Governance

\section{Introduction}

Differences in university administrations exist; therefore, the student participation differs from one country to another. While some higher education institutions have paid attention to the voices of students, many others still consider students of less value to the quality of the institution's administration/ governance. While such students are formally included in university's some decision-makings, their voices are not fully considered, and the

Abdulghani Muthanna

abdulghani.muthanna@ntnu.no; am96715@gmail.com

Haque Shahabul

shahabu14@yahoo.com

Monira Sultana

monirasust@gmail.com

1 Faculty of Political Studies, Shahjalal University of Science \& Technology, Sylhet, Bangladesh

2 Faculty of Social and Educational Sciences, Department of Teacher Education, Norwegian University of Science and Technology (NTNU), Trondheim, Norway

3 Institute of International and Comparative Education, Educational Leadership and Policy, Beijing Normal University, Beijing, People's Republic of China 
purpose is barely to improve the image and the profile of their institutions nationally and internationally.

While the topic of 'student participation' in higher education governance has received much attention (e.g., Carey, 2013; Klemenčič, 2012) with a focus on improving the teaching-learning activity (Trowler, 2010) in the developed nations, it is under-researched in many developing nations. For example, in the Bologna process and the prague declaration, students were considered as one of the key stakeholders in shaping educational policies and practices (Mafa, 2016; Chowdry et al., 2010; Klemenčič, 2012; Prague Declaration, 2001; Sakurai, 2014). Such consideration toward student engagement has become one of the requisite indicators of the institution's educational excellence and effectiveness (Sakurai, 2014). Therefore, many higher education institutions have created different roles for the student participation at the university administration level (Mafa, 2016).

Student participation enhances the planning of academic policies that target the transformation of university culture and improving students' learning outcomes. Many universities are taking efficient and inclusive measures to demonstrate their efforts in supporting student learning outcomes (Sakurai, 2014). However, some higher education institutions still lag behind; they still follow the colonial curriculum (Rahim, 1981) that applies the memorization and 'defective' examination methods (Hossain \& Mohammad, 2015). In Bangladesh, the context of this study, universities still adopt the traditional (lecture-based) methods that offer little participation for students. However, students participate in extracurricular activities. In this study, we focus on answering these three questions: (a) what are the main factors behind students' participation in students' organizations?, (b) how do the students participate in the university decision-making?, and (c) what is the impact of the student participation on students? First, we provide a brief overview of the concept of 'student participation' at universities.

\section{A brief overview of student participation at university}

Student participation is a multi-dimensional concept referring to different features of the student experiences (Carey, 2013; Gunuc, 2014; Haines, 2019; Kahu, 2013; Sharkness \& DeAngelo, 2011; Pike et al., 2006), and intends to encompass salient academic and certain non-academic aspects of the student experiences in educational settings (Coates, 2007). It is also about experiences students bring to higher education institutions. Student participation relates to academic and social integration, student happiness, active learning, student aspiration and representation, and student interaction, performance and retention, student performance in extra-curricular activities, to name a few (Hardy a Bryson, 2010, pp. 20-21). However, learning, identity and administration are regarded as the main tasks/ activities of student participation (Trowler, 2010).

While some universities have produced guidelines for controlling student participation, and students need to have university permission to participate in some activities, many higher education institutions have stable guidelines regarding student participation in university administration. Acknowledging these issues that empower relations between university students and academic staff are challenging and unequal (Robinson, 2012). Further, studying the university's power dynamics is important to understand the experiences of students while implementing their student participation (Mann, 2008) in actuality.

Previous research has divided student participation into four significant cases: (a) the politically-realist case; (b) the consumerist case; (c) the communitarian case; and (d) the democratic and consequentialist case (e.g., Luescher-Mamashela, 2013). As we are 
concerned with the politically-realist case that has a direct relation to our study, it mainly refers to the violent protests or demonstrations frequently occurring in higher education institutions when students do not get formal channels of communication with the authorities (Tamrat, 2016) or when their voices are not considered. The prerequisite for stopping student protests requires student inclusion in university's formal decision-making. Further, the establishment of legal structures for negotiation and communication between student leaders and university authorities helps reduce student political activism in the campus (Bergan, 2004; Boland, 2005; Luescher-Mamashela, 2013). This reflects the importance of student participation in the university's decision-making. It brings about peace and academic stability at campus (Olsen, 2007), and plays a significant role in creating an atmosphere of openness and trust at universities, leading to a positive organizational climate (Menon, 2005).

While these above perspectives on the concept of student participation exist in the western world, it is important to note that studying and reporting upon the concept of 'student participation' differs from one nation to another simply because of the presence of different cultures and education policies. Further, while previous literature details on how 'student participation' is important in decreasing student political activism at campus (Bergan, 2004; Boland, 2005; Luescher-Mamashela, 2013) and creating an atmosphere of openness and trust at university (Menon, 2005), our study enhances such findings and further contributes by reporting on the key factors, approaches and impact of student participation in Bangladesh. While there has been a major global-institutional framing, the effect of the colonialism still appears in many contexts despite the changes in university curricula or even the establishment of new programs (Singh, 2010a, b). In other words, because the concept is under-researched in Bangladesh, we hope that our study contributes to reflecting such local culture and conditions from such a specific context. In Bangladesh, students participate in university administration through student organizations, student union, and issue centric student gatherings. We will detail on such participations in the 9 section.

\section{University administration in Bangladesh}

Generally, two ministries are responsible for the education system in Bangladesh: Ministry of Education (MoE) that is responsible for secondary, higher secondary and tertiary education, and Ministry of Primary and Mass Education (MoPME) that is responsible for primary education. However, different departments also help the two ministries. For instance, the University Grants Commission (UGC), working under the MoE, is responsible for supervising and allocating the government grants for the public universities, and supervises the private universities as well. Further, the Directorate of Secondary and Higher Education (DSHE) is responsible for the state and non-state schools, colleges and madrassas (faith-based schools) at the secondary and higher secondary level.

The university administration is led by the university chancellor, two vice-chancellors and a bureaucratic secretary general (responsible for financial matters). The university chancellor is the administrative chief of the university whereas the vice-chancellors are responsible for maintaining administrative and academic matters. The administration also includes an examination controller, and several provosts of residential accommodations. There is a provost and assistant provost for every residential dormitory. In Dhaka University, several administrative bodies are considered as authorities of the university as shown in Table 1 below (The Dhaka University Order, 1973). With a set of different rules and roles, these governing bodies 
Table 1 Dhaka University administration and students' representatives

\begin{tabular}{llccc}
\hline No. & Bodies & Total affiliates & $\begin{array}{l}\text { Faculties and } \\
\text { others }\end{array}$ & $\begin{array}{l}\text { Students' } \\
\text { representa- } \\
\text { tives }\end{array}$ \\
\hline 1. & Senates & 105 & 100 & 05 \\
2. & Syndicates & 18 & 18 & 0 \\
3. & Academic Councils & 600 & 600 & 0 \\
4. & Boards of Advanced Studies & 180 & 180 & 0 \\
5. & Finance Committees & 09 & 09 & 0 \\
6. & The Planning and Development & 11 & 11 & 0 \\
& Committees & & & \\
\hline
\end{tabular}

administer the university within a general legal framework. However, students' representatives participate only in the Senate administrative body.

\section{Higher education in Bangladesh}

In Bangladesh, universities and colleges offer bachelor, master and doctoral programs. The requirement for gaining admission to universities and colleges is the possession of a higher secondary school certificate (12 years of schooling) (Rabbani \& Chowdhury, 2014).

For obtaining higher education qualifications, students can either enroll in a three-year program followed by a two-year master program, or in a four-year honors program followed by a one-year master program (Monem \& Baniamin, 2010). Universities also offer doctoral programs with a standard period of three years. At present, there are 145 (42 public, and 103 private) universities that contain 29, 374 colleges (13,799 in public universities and 15,575 in private universities) (UGC Annual Report, 2018).

\section{Methods}

In this study, we follow the qualitative case methodology because it examines complex social and educational phenomena (Yin, 2009) while maintaining the significant characteristics of events. With the aim to explore the main factors behind the student participation in student organizations in Bangladesh, the study also reports upon how students participate in university decision-making, and how such participation impacts students' academic and personal lives.

We triangulated the data collection sources, and employed semi-structured interviews, observations and document analysis. The triangulation technique enhances data reliability and lessens any possible biases (Burns \& Grove, 2001). However, it is important to note that this is a case study, and the case university is Dhaka University. Following is a discussion of the main reasons for selecting Dhaka University as the case study.

\section{Criteria for selecting Dhaka University as the sample case}

To avoid any biases, we selected Dhaka University for the following main reasons. First, it was established in 1921, meaning that it is older than Bangladesh that became an 
independent state only 49 years ago (Ahmed \& Iqbal, 2016). Second, it provides an excellent example of a higher educational institution that was founded with a history of massive protests (Manna, 2015). For example, students could make many social and cultural changes, including, for example, the establishment of the Bengali language as the mother language in 1948-1952, the right to education in 1962, the mass uprising 1966-1969, the regaining of social and cultural rights in 1969-1971, the national independence movement in 1971, the restoration of democratic rule in 1982-1990 and the recent changes of quota reform in government jobs in 2018 (Hannan, 2013). Third, such changes/actions have made Dhaka University as an influential actor in the development of higher education and the society in the nation, including most of the job employment. Fourth, graduates of Dhaka University fill more than $60 \%$ of the administrative positions in the governmental sector. Further, most of the political and social leaders of Bangladesh studied at Dhaka University (Ullah, 2013). Fifth, the university is internationally recognised since affiliates like Satyendra Nath Bose and Muhammad Yunus received Nobel Prizes in 1921 and 2006 respectively. Sixth, it is one of the best universities in Asia (Asian Week, 2000), and the top university in Bangladesh (Research Hub, 2017). Following is a presentation of how we collected data.

\section{Data collection procedures and study participants}

To collect in-depth data on the student participation in university administration, and to deeply understand the factors behind such participation, the authors reviewed documents relevant to such issues. The documents included: (a) The Dhaka University Order, 1973 (Ministry of Law, n.d.); (b) Dhaka University 97th Annual Report, 2017-2018 (Dhaka University, 2019); (c) National Report on Sustainable Development (2012); and (d) University Grants Commission Annual Report (2018). Based on the review, we prepared the interview guidelines. After preparing the interview guidelines, the primary author visited the case university and got access to conduct interviews. After getting the participants' consent, he conducted interviews with 25 different participants. He also observed various student activities, visited student organization offices, and participated in different discussion meetings. For a quick accessibility, the primary author recruited a third-year student who helped in locating the places decided by the participants for the conduction of interviews.

For recruiting participants, we developed these criteria. For administrative and faculty members, they should have experience in university administration, student dormitory, and/or participation in student activities. Also, current and former students should have some engagement of student participation, and social and cultural activities.

We grouped the 25 study participants into five categories: university administrators, faculty members, students, former students, and social and cultural activists. Table 2 mentions the key information of the participants.

The interviews were tape-recorded followed by taking notes. The interviews were conducted in the Bengali language to help the participants express their thoughts freely (Muthanna \& Sang, 2019, 2018; Muthanna, 2019).

Regarding the observational research, the primary author also conducted participant and non-participant observations of student activities such as student gatherings, various discussions, and office rooms of student organizations. He also wrote down notes during all observations. 
Table 2 Key information of the study participants

\begin{tabular}{|c|c|c|c|c|}
\hline Pseudonyms & Gender & Profession & Education level & $\begin{array}{l}\text { Years of } \\
\text { experi- } \\
\text { ence }\end{array}$ \\
\hline Interviewee 1 & Male & Administrator and teaching & Ph.D. & 30 \\
\hline Interviewee 2 & Male & Administrator and teaching & Ph.D. & 10 \\
\hline Interviewee 3 & Male & Teaching & Ph.D. & 24 \\
\hline Interviewee 4 & Male & Teaching & Ph.D. & 18 \\
\hline Interviewee 5 & Female & Teaching & Ph.D. & 10 \\
\hline Interviewee 6 & Female & Researcher & Graduate & 03 \\
\hline Interviewee 7 & Male & Student & Undergraduate & None \\
\hline Interviewee 8 & Male & Student & Graduate & None \\
\hline Interviewee 9 & Male & Student & Undergraduate & None \\
\hline Interviewee 10 & Female & Student & Undergraduate & 02 \\
\hline Interviewee 11 & Male & Politician & Graduate & 35 \\
\hline Interviewee 12 & Male & Journalist & MPhil & 15 \\
\hline Interviewee 13 & Male & Student & Graduate & None \\
\hline Interviewee 14 & Male & Organizer & MPhil & 10 \\
\hline Interviewee 15 & Male & Student & Graduate & None \\
\hline Interviewee 16 & Male & Student & Undergraduate & None \\
\hline Interviewee 17 & Male & Student leader & Graduate & 09 \\
\hline Interviewee 18 & Female & Student and cultural activist & Graduate & 03 \\
\hline Interviewee 19 & Male & Debater & Graduate & 05 \\
\hline Interviewee 20 & Male & Student leader & Graduate & 04 \\
\hline Interviewee 21 & Male & Journalist & Graduate & 07 \\
\hline Interviewee 22 & Male & Student and journalist & Graduate & 04 \\
\hline Interviewee 23 & Male & Cultural activist & Graduate & 05 \\
\hline Interviewee 24 & Male & Social activist & Graduate & 07 \\
\hline Interviewee 25 & Male & Student representative & Undergraduate & 02 \\
\hline
\end{tabular}

\section{Data interpretation}

By reviewing the relevant documents listed above, we could prepare the interview guidelines that mainly focus on exploring the participants' experiences and views on the student participation in the university administration. In our review of documents, we highlighted some statements that we used in the interviews. This is significant as it helps compare the experiences of the study participants with such statements. For example, when the Dhaka University Order of 1973 states that managers of dormitories and residential teachers should perform the duties of management at the student dormitory, the participants evidenced that this is not implemented at the studied university, and this is further discussed under the subtheme '4.2.2 Student organizations.'

For interpreting data collected through interviews and observations, we followed the grounded theory (e.g., Charmaz, 2014). In detail, after transcribing the tape-recorded data in the Bengali language, the primary and third authors translated the transcriptions into the English language. The authors reviewed the translated transcriptions many times for coding purposes (Weiss, 1994). We initially created 23 codes which we later developed into 
14 larger codes. Further readings of the coded texts helped in developing several themes. Further readings of the themes led to developing three main categories.

Here is an example of how we developed codes, themes and categories. Reading through the data, we developed codes such as (SO) student organization, (PRPSO) personal reason of participating in student organizations, (ER) environmental reason and (OR) organizational reason. Then we developed these codes into several themes, including student organization activities, university administration, student union, university accommodation, extra-curricular activities, socio-economic status of Bangladesh, social stratification, job facilitation in Bangladesh, higher education system and so on. Afterwards, we condensed such themes into three main categories with subthemes as shown in the following section.

\section{Findings}

\section{The key factors for student participation}

Students participate in student organizations and perform in several extracurricular activities for many different reasons. The key factors are discussed in the following sub-themes. These key factors are listed and discussed below in accordance with their significance and priority for the study participants. While we discuss the types of student organizations in the second major theme, it is necessary to note that the factor for student participation decides the type of student organization the students prefer to get engaged in.

\section{To secure a place in a dormitory}

Securing a place in a dormitory is the most influential factor behind student participation in students' organizations and activities. Students' residential dormitories play an essential role in the academic and non-academic lives of students. When students live in comfortable dormitories, they can study well, and participate in some student activities. This is not well achieved at the university being studied. The number of places/rooms in dormitories is much fewer than that of students, leading to a continuous accommodation crisis. The university has 12,000 dormitory-seat arrangements for around 30,000 students, meaning that only $40 \%$ of students could get accommodation facilities (University Grants Commission Annual report, 2018). Therefore, getting a dormitory seat is a challenge because large numbers of students apply for the university dormitory annually.

The fees for university dormitories are low because the main purpose is to help students (particularly those with low-income families). In addition, the government provides subsidies on significant facilities including dining, library, reading room, free Wi-Fi, and gymnasium. However, the number of low-income students is increasing. This is further highlighted in the following faculty member's quote.

Public universities have been experiencing many demographic changes in recent years. In the past, middle class, urban or semi-urban students were in the majority at university. There were few possibilities for poor students to come to the university level in the past. Now, the opportunities for students from low-income families are increasing; as a result, the children of low-income people are coming to Dhaka University in the majority. Interviewee 4. 
The increase of students in higher education has made it challenging to accommodate all students in university dormitories. It is further challenging at Dhaka University. Student participants expressed their unhappy feelings concerning this issue. This is evidenced by the following voices.

It is easy to get admitted at the university, but it is very difficult to get a seat in the residential area. It is possible to get admission in the university if students study well although there are many candidates. However, admission in Dhaka University does not mean that students are guaranteed a seat in the residential dormitory. Interviewee 7.

Finding seats in a residential dormitory is a complex process. I became mentally weak to face this process after being admitted at the university. I went to many students and talked to them. I got the opportunity to stay in a residential hall three months after admission to the university. Interviewee 6.

Facing several challenges from the outset of university life makes students feel unhappy. According to the student participants, many university students do not have sufficient resources to help rent a house or apartment in Dhaka city. Therefore, students compete in securing a place for living in university dormitories. As student organizations work as major actors in maintaining, deciding, and arranging the places/seats of the university's dormitories, students' participation in student organizations becomes a decisive factor in helping students to secure places at dormitories. This increases the power of the student organizations, and the obligation of students' loyalty to such student organizations. The following evidence states the participants' views on the current situation of dormitory facilities.

The principal reason for participating in student organizations is to secure the seat at the dormitory, as most of the Dhaka University students, like me, are financially weak. They cannot afford off-campus accommodation. Interviewee 9.

When the students get admitted to the university, they need accommodation, and they go to student organizations to get a seat as the organizations maintain the accommodation system. It has been developed for many years. Interviewee 14 .

These statements show how student organizations can exercise their power in managing dormitories and forcibly engage students in their organizations. Student organizations' control and influence of university dormitories is a long-term process. In principle, the dormitory administrators and residential tutors are responsible for officially managing dormitories. Residential tutors are appointed as faculty members of university, and they, according to the university laws, supervise the dormitory works besides their teaching and research activities. In return, residential tutors get residential benefits and a financial allowance from the university. However, they show little interest in doing so, shifting such power to student organizations. This is depressing for many students and demands a reform. For example, interviewee 13 mentioned that dormitory authorities and student organizations need to collaborate and facilitate the accommodation processes. Further, the participant proposed that the process of the student's admission into dormitories should go hand in hand with their admission into the university. Meanwhile, the participant interviewee 10 mentioned that she has lived at her sister's house temporarily after getting admission to the university. Her sister and other relatives helped the participant to find and communicate with a student leader, which gave her the opportunity to get a seat in the dormitory. This, of course, accentuates the power exercised by student leaders. It also shows the presence of networking that helps in securing places at 
dormitories. This in turn negatively affects those who do not have networks or who do not have people to support them.

\section{Effect of family traditions}

It is normal that families influence their children. This influence can also accompany children to the university life. In the context of Dhaka University, a significant number of students are influenced by their families who highlight the importance of participating in university activities. The student participants informed that they have acquired preliminary social and cultural knowledge from their family. They also reflected on how family traditions are influencing them in performing in various cultural activities at an early age. Such an early age participation geared by families also continues to the university level. Below are evidence statements from students indicating the family background.

A substantial number of students have been involved in socio-cultural activities during university life because of their family background. I have several friends in the university who are engaged in socio-cultural activities due to their family backgrounds. Interviewee 13.

I observed from my school-age that my elder brother had a habit of writing short stories; I also tried to follow him at that time. After being admitted to Dhaka University, I started to write short stories, novels, and features in different daily newspapers. Interviewee 14.

Families constitute the main foundation of children's learning (e.g., Abbott, 2002; Hallinan, 2005) habits and actions. The above quotations highlight such sense and the students' participation in extra-curricular activities. Family traditions coupled by inspirations are of vital importance to the continuity of participation in different activities. On the other hand, some participants (e.g., Interviewee 7 and Interviewee 19) indicated that family influence might not frequently impact on their participation in any other activities during university life. Students have changed their participation in particular activities after joining the university. This is further discussed in the following sub-themes.

\section{Individual preference}

Many students participate in a variety of activities because of their individual preferences. When some activity interests them, they join and participate in it. In other words, some students participate in various activities because of their passion and love for particular types of activities, believing that their participation can satisfy their passion in practice. Here is evidence.

As an individual, it is not possible to turn an activity into reality, but when a good number of people think and work together, it is then easier to make it practical. Interviewee13.

In this case, universities need to help such students increase and sharpen their interests and thoughts and get them realized in reality. The interviewees mentioned that students have diverse experiences and that universities need to make use of such experiences and interests. Young students are energetic and could spend some time to think about society, politics, and culture. Many of them are also ready to participate in activities that have good impact on society (interviewee 2). A further example is given below. 
University students are not entirely equal in their thoughts and attitudes. [For instance,] like several [students] are interested in cultural activities while few [students] like debating or public speaking. So, they get involved in such activities. In my case, I was attracted to politics since my childhood. So, I became a member of the student organization after admission. Interviewee 20.

Most student organizations have different lists of activities; however, this still depends on students' willingness, and students may have individual opinions about their affection (Interviewee 24). For instance, the interviewee 24 gave an example of a student who likes dancing with great passion. Therefore, she joined the student organization to get a chance to dance and improve her dancing skills. Personal interest is essential for students to participate and therefore it is the responsibility of higher education institutions to nurture such interests by providing a diversity of activities.

\section{Future career and leadership skills}

The study participants also stated that many students participate in a diversity of extracurricular activities to shape their future careers. Many students enter university, intending to make their future better. In addition, students are concerned about the severe unemployment challenge in the country; therefore, students take part in such activities with an expectation that such participation would enhance and improve their skills necessary for their future careers. In this respect, many students have set their career goals before or after being admitted into the university, and they select activities consistent with their target goals. Several participants commented on the personal choices of students' participation based on future career goals, and we present two unique experiences of participants below.

I have observed that most of the students at Dhaka University join different clubs like debating club, photography club, recitation club, writing club, reading club, and sports club based on their talent and preference. They join these organizations to develop their skills and receive and give something worthy to the society. Interviewee 13.

Dhaka University has been contributing to the nation and national government for the last five to six decades. A considerable number of national leaders were students at Dhaka University, and they were ... participants of student activities. It is an opportunity for students at Dhaka University to involve in student activities, to establish a link with a few national leaders. It inspires student activists to enter nationallevel politics. Interviewee 16.

For further planning of future careers, some students believe that participating in activities would help gain knowledge and experience needed for the uncertain future. For example, participating in activities wherein students make oral presentations demand students to join a debate club that focuses on presentation skills improvement.

In addition, development of leadership skills is another key factor motivating students to participate in activities prepared by student organizations. Students have the opportunity to develop leadership skills through performing leadership roles at different student organizations. The participation in social and political activities during the student life can gradually prepare students to be future leaders of the nation. Students are also aware of the fact that Dhaka University has been a good example for preparing future national leaders; a substantial number of national leaders were qualified at Dhaka University. Further, many existing student leaders of different organizations at Dhaka 
University have become members of Parliament (National legislature of Bangladesh) and play a vital role in the legislative council. In this regard, one participant reflected their view, stating the following.

Students participate in different organizations to develop their leadership qualities. They engage in various clubs, for instance, debating clubs, film clubs, reading clubs, and other cultural bodies. Interviewee 14.

The above quote signifies the importance of participating in various social and cultural organizations as an initial driving force to develop leadership skills. Within student organizations, students can manage affiliating members, and arrange different activities. Such practical experience is valuable for future events.

\section{Approaches for student participation in university administration}

There are mainly three approaches for students to participate in university administration: student union, student organizations, and issue centric activities. We discuss these approaches in the following subthemes.

\section{Student union}

Dhaka University Central Student Union (DUCSU) is a student, election-based body that represents students' thoughts, preferences, beliefs, rights, etc. The DUCSU representatives play an essential role in the university decision-making through having the voting right to participate in electing a vice-chancellor of the university. However, it is not clear why the vice-chancellor of Dhaka University is the president of the DUCSU. While this might enable frequent interaction and communication among university administration and DUCSU leaders, it might also indicate the control of power. Regardless of this power structure, the student representatives communicate the students' opinions with university leaders, denouncing any issues going against students' needs and interests. The following two statements show the participants' experiences on the roles of the DUCSU.

\footnotetext{
Dhaka University Central Student Union has numerous functions; it is the elected representative of the student bodies. Whenever these representatives speak on any relevant issues, it has a higher value, from the perspective of the university as well as the whole country. And dormitory parliament representatives have significant influence among student dormitories. Interviewee 14.

Dhaka University Central Student Union has representation in the Senate ... The vice-chancellor presides the meetings of Dhaka University Central Student Union, and students present their opinions to the president, which is just the same [way] as offering their views to the administrative head of the university. Interviewee 21.
}

The DUCSU is the link between students and university leaders. For instance, the student representatives highlighted some student issues such as reduction of the tuition fees, increase of dormitory facilities, and provision of library resources in the last Senate meeting held in June 2019. The university authorities, according to interviewee 22, assured student representatives to implement students' demands gradually. 


\section{Student organizations}

Student organizations have played a considerable role at Dhaka University and in the national politics. Student organizations refer to students' efforts toward realizing the interest of students and serving students' community (Alam et al., 2011; Giddens \& Sutton, 2017). Further, when a group of students work together toward some selective goals within an educational institution, it is then called student organizations (Patwary, 2011). There are 50 student organizations working in Dhaka University, of which 23 receive a financial support from the university administration for organizing different activities (Dhaka University Annual Report, 2018). Such student organizations are classified as social, political, cultural, and regional entities. For example, the main activities of the cultural organization are based on culture; students who have interests in culture join a cultural organization. Cultural activities refer to the performance of dancing, singing, reciting poems, and playing musical instruments. The cultural organization recruits students and provides them with some training. Besides, the social student organization is basically formed on different social issues. Additionally, the political student organization is formed based on different ideologies such as secularism, marxism, leninism, liberalism, socialism, nationalism, and islamism (Jahan, 2014). Generally, all student organizations have their constitutions and organizational structures. These constitutions operate these organizations. The organizations are managed through monthly subscriptions of members, donations from the wellwishers, and the university administration contribution.

Student organizations have an influential role in the university decision-making. They take part in the decision-making through various ways as revealed by participants, and the following evidence uncovers student's influence on the university's decision through student organizations.

Student organizations do have an influence. There is an invisible barrier between students and the administration. From the perspective of our country, teachers are highly respected. Raising voice in front of teachers is regarded as an offense. Teachers cannot mix with students properly to maintain their image. Now, student organizations help the administration to understand students' psychology. Interviewee 16.

Another participant explains how the university administration deals with these matters, stating the following.

The university administration's response depends on the students' approach. If students show patience and convince the administrators, their demands can be fulfilled. But when students appear in groups, they usually cause fear, which may work against them. If students are organized and send their representatives who have a convincing ability, then there can be a solution. But in most cases, students do not show that capability, and so their demands are not fully met. Interviewee 18.

The vice chancellor of Dhaka University (interviewee 1) informed that the student organizations:

... have a significant contribution to our national history. They work for the students in the university. They used to come to us with various students' issues, [and] we sit and talk with them.

The statement indicates that student organizations have an influence on the university administration that responds to students' demands. Student organizations follow various 
policies to influence the university administration. In particular, some student organizations have political connections, and they have control over student dormitories, dormitory canteens, and cafeterias. Further, some student organizations exercise their networking and positions power to appoint their preferred candidates at several academic and non-academic positions of the university (interviewee 14).

Student dormitories are also managed by student organizations. Dhaka University has 23 student dormitories: 16 for male and 7 for female students (Dhaka University Annual Report, 2018). As stated by The Dhaka University Order of 1973, managers of dormitories and residential teachers should perform the duties of management at the student dormitory. However, the study participants confirmed that student organizations have been managing dormitories for decades. This includes allocation of seat arrangements, and management of canteens, cafeterias, and student activities. Although all residential teachers have been assigned some responsibilities for dormitories according to the rules, students do most of the work (interviewees 25 and 13). Some participants elaborated on students' influence on the dormitory in the following statements.

I think that about half of the students stay in the dormitory. When new students come to the dormitory to stay, the student organizations assist them in settling down. Later, they often call these students to take part in political activities. Interviewee 25.

.... Student organizations have an authority in various affairs related to their dormitories like the canteen, cafeteria, and student seat arrangement. Interviewee 13.

The above evidence illustrates student organizations' authority in the student dormitories. In particular, student organizations' supervision begins when new students arrive at dormitories for the allocation of rooms. In addition, student organizations assign food managers at the dining hall and canteen managers at the cafeterias. Student organizations manage the dining hall directly while giving canteen on contract basis to non-administrative people.

Moreover, student organizations also supervise cultural and social events at the dormitory and provide opinions on events and guest selections (Interviewee 14). While several participants positively perceived student participation in the dormitory, many other participants expressed dissatisfaction. They informed that student's supervision creates a discrepancy because a large number of students could not get their expected seats and receive low food quality and disadvantaged study housing facilities (interviewees 20, 14, and 25), resulting in the presence of some complaints.

\section{Issue centric student gathering}

Students raise their voices concerning some institutional issues at different times. For example, students have some typical demands to increase the facilities of the student dormitories, reduce the student fees, provide more books in the central library, increase the number of classrooms, improve the food quality in the canteens, build more residential dormitories, to name a few. Some issues become more prevalent at different times, and hundreds of students gather and participate in raising/achieving their demands. To publicize such issues, students perform demonstrations, human chains, dialogues, and cultural programs. With such issue-centric student activities, students aim to influence the university administration.

A few issues have become popular at Dhaka University in the last three years, which were reported mainly by many participants. These issues relate to the introduction of 
evening courses in various departments, the questioning of the appearance of admission tests prior to taking them, the presence of accommodation crisis, quota reformation movement, the affiliation of seven colleges with Dhaka University, and the regulation of DUCSU election. Most of these issues were minor in the beginning but gradually turned into significant points through the participation of numerous students. Our observations also confirm the gathering of several hundred students on several issues. One participant reflected their experience on how students gather for an issue as follows.

Initially, social media facilitates propagating students' demands to raise one issue. Students spread information on social media and then unite to show their stance. Students organize several open conversations on specific issues, teachers also participate in such gathering, and students speak their problems. In addition, students gather in public places and arrange various programs for their problems. Interviewee 25 .

The above reflection shows the power of social media in spreading the information on campus that gradually turns one issue into an important subject. University authorities feel pressured only when students gather in large numbers and invite student representatives to discuss the matter (interviewee 25). Student gatherings and their discussions with university authorities slowly move towards a solution where attempts are made to uplift the interests of the students (interviewee 22). The study participants informed that student gatherings on specific issues make university authorities accept the demands of students in many cases.

\section{Impact of student participation}

Student participation in student organizations has a positive impact on students' academic and personal lives. In detail, the participants believe that participating in various activities helps get an opportunity to show students' talents and improve their skills. Students can attend many extra-curricular activities of their interests besides their studies. The following evidence reveals that students benefit from participating in extra-curricular activities provided by student organizations:

\section{All these [student] organizations have a considerable impact on students. Students can learn different sets of skills for adaptation, and recognize their ability to get ben- efits from opportunities, and develop their skills as qualified and competent students. Interviewee 24. \\ It is encouraging that students take an active role in administrative work at the uni- versity, as it helps students to take their responsibilities, and it builds a sense of cooperation and management among them. Interviewee 6.}

This evidence shows the benefits for participating in extra-curricular activities. Students could gain skills and knowledge by contributing to the management of student dormitory, which may be useful for their future work (Interviewees 2 and 15). Different activities provide students with extra confidence to participate in diverse tasks. Interviewee 2 also highlighted that dormitory management and other activities facilitate students' development of managerial and leadership skills. The participants also informed that extra-curricular activities help students to improve their mental and physical health.

Additionally, many participants stated that students' multitasking ability could be developed through student participation in student organizations. Several skills, such as the skill 
of negotiation, skill of collaboration, and other human abilities are developed through students' participation in student organizations. Further, many students gain organizational competence by participating in student organizations that help develop communication skills. For example, student participation in the dormitory seat management could help students to learn how a dormitory functions, and how different student activists communicate with students and with dormitory authorities. Through participating in the student organizations of the dormitory, students could develop and enhance a collaborative attitude to work with one other (Interviewee 16). Since student dormitory is a place for students of different academic backgrounds and different regions, cultures, societies, and families, students learn management skills to live and adjust with one another.

Moreover, student participation results in developing leadership skills. Student organizations have many other functions and activities within and outside of organizations. They meet students from different levels. To make the organizations stronger, they recruit students, and organize various activities for them. Student organizations also negotiate with the university administration on various issues. This process has made students cultivate individual leadership skills.

Furthermore, many participants believed that students participating in diverse activities show better academic results than those who do not participate in university activities. They appreciated that students could gain additional knowledge through participating in social and cultural events, which are of value to students' academic life (Interviewees 14 and 17). One participant also commented as below.

Participating in activities has helped me much in my academic [studies], because, for a professional debater, it requires updated knowledge for the current affairs. I also must study many books for in-depth knowledge and remember references for statements that I make in my debates. Likewise, various organizations require students to be good at different aspects, which eventually assist them [become] better [in] their academic learning. Interviewee 24.

The above statement reveals that students are required to study more for extra-curricular activities, which help students to develop a learning habit. However, some participants informed that some students receive poor academic results despite their participation in extra-curricular activities (Interviewees 2 and 20). Interviewee 3 stated that some students have dropped out due to spending more time in dormitory activities. He firmly expressed that students invest more time in other activities on campus, such as student union elections and student organizations' activities. This means that student organizations also need to rethink of the number of activities students can participate in so that they can balance between such activities and their studies.

\section{Discussion and conclusion}

Previous literature details on how 'student participation' is important in decreasing student political activism at campus (e.g., Bergan, 2004; Boland, 2005; Luescher-Mamashela, 2013) and creating an atmosphere of openness and trust at university (Menon, 2005). In addition to supporting the previous studies, the originality of our study lies in detailing the key factors, approaches and impact of student participation in Bangladesh. In other words, our study has attempted to uncover the key dynamics behind student participation in 
student organizations and student union in higher education in Bangladesh, and reports on how such participation impacts students academically and professionally.

The key factors for participating in student organizations relate to securing a dormitory seat, which unfortunately cannot be gained unless students become members of such organizations. The exercise of such power by student organizations representatives is not positive for those who are not interested in performing extra-curricular activities. Further, it is not positive for students applying for administrative and academic jobs since student organization representatives can also use their power in supporting their relatives and friends in obtaining such jobs. Another factor for joining student organizations associates with the effect of family traditions over their children. It is positive that children start developing some skills and talents from an early age due to the influence of their family members, and that such an effect continues to an adulthood. However, many students also join student organizations for the sake of fulfilling their personal interests. Most importantly, many students participate in extracurricular activities organized by student organization for the sake of developing and enhancing certain skills that help them receive jobs of their choice after graduation. This positively reflects students' strategic thinking that universities need to enhance further. Students train themselves according to their aims by participating in extra-curricular activities of their choice.

Our findings also report upon the different approaches that students can employ for participating in university administration. The findings mainly report of three main approaches: student union, student organizations, and student issue centric gatherings. In detail, with the right to vote in electing a vice-chancellor of the university, the student union representatives can then communicate the students' thoughts and interests with the leaders of the university. While it is not clear why the vice-chancellor is the president of the student union, the student union representatives can still have an influence on university decision-making through either negotiation with decision makers or gathering students to protest against decisions students do not accept. Such gatherings, known as issue centric student gatherings, also influence a change of university decisions on several issues. The gathering of hundreds of students forces university leaders to accept the demands of students. Another approach of participating in university administration is through student organizations that administer student dormitories and canteens. While some participants positively viewed the control of student organizations over dormitories and canteens, many study participants also reflected dissatisfaction with such control because it resulted in the presence of discrepancy among students, and a low quality of food and housing facilities.

Additionally, our findings report on the presence of several benefits behind the student participation in student organizations. The main benefits relate to the development and enhancement of different skills such as negotiation and communication. In particular, the student participation in extra-curricular activities helps develop management and leadership skills, a collaborative and teamwork attitude, build students' confidence, maintain students' positive mental and health development, which are also of paramount importance in achieving positive academic results.

In conclusion, while student participation in different extra-curricular activities is significant in developing students' current and future skills, fulfilling their interests, and building their confidence, the students need to be selective of their representatives so that the issue of discrepancy and the use of power in distributing dormitory seats or appointing relatives would decrease. Further, while student union, student organizations, and issue centric student gatherings can influence university decisions, administrations of universities need to rethink of including students' representatives in the formulation and implementation of their institutional policies. Additionally, by formulating clear guidelines for student 
participation the universities can maintain a healthy and organizational environment that is of high significance to students' current and future academic and non-academic success.

Acknowledgements We acknowledge the participations of our study participants.

Author contributions All authors contribute equally to the development of this study.

Funding Open access funding provided by NTNU Norwegian University of Science and Technology (incl St. Olavs Hospital - Trondheim University Hospital).

\section{Declarations}

Conflict of interest The authors declare that they have no conflict of interest.

Ethics declarations We declare that we have obtained participation consent from our study participants prior to conducting interviews and observations.

Open Access This article is licensed under a Creative Commons Attribution 4.0 International License, which permits use, sharing, adaptation, distribution and reproduction in any medium or format, as long as you give appropriate credit to the original author(s) and the source, provide a link to the Creative Commons licence, and indicate if changes were made. The images or other third party material in this article are included in the article's Creative Commons licence, unless indicated otherwise in a credit line to the material. If material is not included in the article's Creative Commons licence and your intended use is not permitted by statutory regulation or exceeds the permitted use, you will need to obtain permission directly from the copyright holder. To view a copy of this licence, visit http://creativecommons.org/licenses/by/4.0/.

\section{References}

Abbott, J. (2002). To be intelligent. California Journal of Science and Education, 2(2), 5-18

Ahmed, I., \& Iqbal, I. (2016). University of Dhaka, making, unmaking and remaking. Prothoma Prokashan

Alam, G. M., Rabby, T. G., Boon, T. L., Khan, I., \& Hoque, K. M. (2011). National development and student politics in Bangladesh. African Journal of Business Management, 5(15), 6044-6057

Asian, W. (2000). Asia's best universities 2000: University of Dhaka. Asian week

Bergan, S. (2004). Higher education governance and democratic participation: The university and democratic culture. In S. Bergan (Ed.) The university as res publica (pp. 8-30). Council of Europe Higher Education Series No. 1

Boland, J. (2005). Students participation in shared governance: A means of advancing democratic values? Tertiary Education and Management, 11(13), 199-217

Burns, N., \& Grove, S. K. (2001). The practice of nursing research: conduct, critique and utilization (4th ed). WB Saunders

Carey, P. (2013). Student engagement in university decision-making: policies, processes, and the student voice. Lancaster University (doctoral dissertation)

Charmaz, K. (2014). Constructing grounded theory (2nd ed.). Sage

Chowdry, H., Crawford, C., Dearden, L., Goodman, A., \& Vignoles, A. (2010). Widening participation in higher education: Analysis using linked administrative data. Journal of the Royal Statistical Society, 176(2), 431-457

Coates, H. (2007). A model of online and general campus-based student engagement. Assessment \& Evaluation in Higher Education, 32(2), 121-141

Dhaka University. (2019). Dhaka University 97th Annual Report 2017-2018. Dhaka, Bangladesh

Giddens, A., \& Sutton, P. W. (2017). Sociology (8th ed.). Polity Press

Gunuc, S. (2014). The relationships between student engagement and their academic achievement. International Journal on New Trends in Education and Their Implications, 5(4), 216-233

Haines, K. (2019). Student perspectives on joining student organizations. Northeastern University Boston (a doctoral dissertation) 
Hallinan, T. (2005). The normative culture of a school and student socialization. In Larry, B. S., \& Hedges, V. (Eds.) Social Organization of Schooling (pp. 129-150). Russell Sage Foundation

Hannan, M. (2013). History of student movement in Bangladesh 1830-1971. Agami Publications (in Bengali)

Hardy, C., \& Bryson, C. (2010). Student engagement: Paradigm change or political expediency? Networks Magazine, 9, 20-23

Hossain, M. M., \& Mohammad, A. M. (2015). Higher education reform in Bangladesh: An analysis. Workplace, 25, 64-68

Jahan, R. (2014). Political parties in Bangladesh. Center for Policy Dialogue

Kahu, E. R. (2013). Framing student engagement in higher education. Studies in Higher Education, $38(5), 758-773$

Klemenčič, M. (2012). The changing conceptions of student participation in HE governance in the EHEA. In Curaj, A., Scott, P., Vlasceano, L., \& Wilson, L. (Eds.), European Higher Education at the crossroads (pp. 631-653). Springer

Luescher-Mamashela, T. M. (2013). Student representation in university decision making: Good reasons, a new lens? Studies in Higher Education, 38(10), 1442-1456

Mafa, O. (2016). Involving students in university governance: Perceptions of open and distance learning students. Journal of Research \& Method in Education, 6(2), 49-54

Mann, S. (2008). Study, power and the university. Open University Press

Manna, M. (2015). Student politics of Bangladesh, past, present and future,(Bangladesher Chhatra Rajniti, Otit,brotoman, and vobishat). Rukkhu Shah Creative Publishers (in Bengali)

Menon, M. E. (2005). Students' views regarding their participation in university governance: Implications for distributed leadership in higher education. Tertiary Education and Management, 11(2), 167-182

Ministry of Law. (n.d.). The Dhaka University Order, 1973 (President's Order). Available at: http:// bdlaws.minlaw.gov.bd/act-details-447.html

Monem, M., \& Baniamin, H. M. (2010). Higher education in Bangladesh: Status, issues, and prospects. Pakistan Journal for Social Science, 30(2), 293-305

Muthanna, A., \& Sang, G. (2019). State of university library: Challenges and solutions for Yemen. The Journal of Academic Librarianship, 45(2), 119-125

Muthanna, A., \& Sang, G. (2018). Conflict at higher education institutions: Factors and solutions for Yemen. Compare: A Journal of Comparative and International Education, 48(2), 206-223

Muthanna, A. (2019). Critical qualitative inquiry and methodological awareness: The effectiveness of face-to-face interviews in changing/enhancing participants' beliefs and practices. International Journal of Research Studies in Education, 8(2), 59-66

National Report on Sustainable Development (2012). Rio+20: National Report on Sustainable Development. Dhaka, Bangladesh. Avialable at: https://policy.asiapacificenergy.org/sites/default/files/Rio\% 2B20_Bangladesh_reduced.pdf. Accessed 5 Jul 2019

Olsen, J. P. (2007). The institutional dynamics of the European university. In Maassen P., and Olsen, J. P. (pp. 25-54). University dynamics and European integration. Springer

Patwary, M. E. U. (2011). Recent trends of student politics of Bangladesh. Society and Change, 5(4), $67-78$

Pike, G. R., Smart, J. C., Kuh, G. D., \& Hayek, J. C. (2006). Educational expenditures and student engagement: When does money matter? Research in Higher Education, 47(7), 847-872

Prague, \& Declaration (2001). Towards the European higher education area: Communiqué of the meeting of European ministers in charge of higher education in prague. Available at: http://www. encore-edu.org/ENCoRE-documents/prague.pdf. Accessed 10 June 2020

Rabbani, G., \& Chowdhury, S. (2014). Quality of higher education in Bangladesh: Governance framework and quality issues. Beykent University Journal of Social Science, 7(1), 78-92

Rahim, A. (1981). The History of the University of DACCA. University of DACCA

Research Hub. (2017). Bangladeshi University Ranking 2017. Research Hub

Robinson, C. (2012). Student engagement: What does this mean in practice in the context of higher education institutions? Journal of Applied Research in Higher Education, 4(2), 94-108

Sakurai, Y. (2014). Understanding factors contributing to the academic management of international university students. The University of Helsinki, Institute of Behavioural Sciences

Sharkness, J., \& DeAngelo, L. (2011). Measuring student involvement: Acomparison of classical test theory and item response theory in the construction of scales from student surveys. Research in Higher Education, 52, 480-507 
Singh, M. (2010a). Higher education research: global themes and local settings a research report. CHER. Available at: http://oro.open.ac.uk/21274/1/Higher_Education_and_Society.pdf. Accessed 30 Oct 2021

Singh, M. (2010b). Re-orienting internationalisation in African higher education. Globalisation, Societies and Education, 8(2), 269-282. https://doi.org/10.1080/14767721003780439

Tamrat, W. (2016). Student participation in higher education governance: Trends and practices in ethiopian public universities. The Teacher, 7(14), 1-14

Trowler, V. (2010). Student engagement literature review. The Higher Education Academy

Ullah, S. A. (2013). Student politics in Bangladesh under military autocracy. Asian Studies (June Issue), No.32

University Grants Commission Annual Report (2018). University Grants Commission Report of Bangladesh. Bangladesh. Retrieved April 8, 2021, from http://www.ugc.gov.bd/site/annual_reports/ed1ed 68d-c017-4e3e-a66c-ba1fb83fc0bc/Annual-Report-2018

Weiss, R. S. (1994). Learning from strangers: The art and method of qualitative interview studies. Free Press

Yin, R. K. (2009). Case study research: Design and methods (4th ed.). Sage

Publisher's Note Springer Nature remains neutral with regard to jurisdictional claims in published maps and institutional affiliations. 